DOI https://doi.org/10.18551/rjoas.2018-06.15

\title{
AN EMPIRICAL STUDY ON ACCEPTANCE OF TECHNOLOGY BASED INFORMATION SYSTEMS BY PROPERTY MANAGEMENT EMPLOYEE
}

\author{
Kadek Supartini*, Budiasih Igan, Suardikha I Made Sadha \\ University of Udayana, Bali, Indonesia \\ *E-mail: kadek.adde@gmail.com
}

\begin{abstract}
The purpose of this study is to know the effect of acceptance in the use of Micros Fidelio information system on Property Management employee using external factor, namely institution factor and individual factor using Technology Acceptance Model framework. The research model was made to verify fourteen hypotheses in modeling technology acceptance. The population in the study was permanent employees of property management companies consisting of hotel, villa and restaurant divisions. Since the population consists of divisions within a business unit, proportional sampling was used as the sampling technique. 115 respondents were used as samples within the period of December 2017 until January 2018, because the testing of Micros Fidelio information system began to be applied. Models and hypotheses will be tested and processed using PLS 3.0 software.
\end{abstract}

\section{KEY WORDS}

Management commitment, self efficacy, personal innovativeness, perceived usefulness, behavioral intention.

Property management is a company engaged in the field of tourism that provides accommodation services, food and beverages, entertainment for tourists. Therefore, the services provided are the main thing of concern, because it will impact on business continuity and customer satisfaction (Normasari et al, 2013). Support it to the information technology system used must be proper so that goal can be realized. The alteration of information technology system used from Raptor to Micros Fidelio was expected to increase the company's profit financially and non-financially. Raptor is a hotel and restaurant program in the form of software and specially designed by using touch screen to administer company transactions such as sales transaction, purchase, inventory, and cost of goods sold. In the processing of complex financial reports Raptor requires integration with other back office software, resulting in problems in terms of time, cost benefit for the company.

Table 1 - Differences between Raptor and Micros Fidelio

\begin{tabular}{|c|c|c|c|}
\hline No & Item & Raptor & Micros Fidelio \\
\hline 1 & Server & $\begin{array}{l}\text { The database not consolidated in } \\
\text { one system }\end{array}$ & $\begin{array}{l}\text { The database consolidated in } \\
\text { one system }\end{array}$ \\
\hline 2 & User & $\begin{array}{l}\text { Noncustom mode means that } \\
\text { previous inputs can not be } \\
\text { changed or deleted because their } \\
\text { historical data will change }\end{array}$ & $\begin{array}{l}\text { Custom mode means the } \\
\text { previous input can be changed } \\
\text { and does not change the } \\
\text { transaction history }\end{array}$ \\
\hline 3 & Terminal Access & Emulator (telnet) & Browser (internet) \\
\hline 4 & Network & $\begin{array}{l}\text { Frame relay means that data can } \\
\text { only be accessed at certain } \\
\text { places connected to the server }\end{array}$ & $\begin{array}{l}\text { Backup line (icloud) means that } \\
\text { data can be accessed any time } \\
\text { with internet network provided. }\end{array}$ \\
\hline 5 & Security & $\begin{array}{l}\text { Server Raptor means file and } \\
\text { data storage only on the server }\end{array}$ & $\begin{array}{l}\text { Server and Network (Active } \\
\text { directory) means the storage of } \\
\text { data and files on the server and } \\
\text { connected network. }\end{array}$ \\
\hline
\end{tabular}


While Micros Fidelio is a software that is integrated directly throughout the company and can process complex corporate transactions and is expected to be able to produce more accurate information, and timely for management in making decisions for both outside parties and the company internaly.

The company expected the employees to accept and use the Micros Fidelio system, so that in December 2017 the system has been piloted to the managers. They are the ones who will provide instructions and solutions to employees if there are difficulties and errors in the application system. While in January 2018 it began to be tested to the employees of the company. This was done to provide an initial picture of the system. System changes take time in the transition process, which will lead to employee conflict in the adaptation process. Compeau and Higgins (1995) states that the critical stage in the application of an information technology system is the condition of the presence of the system accepted or rejected by potential users. User acceptance or rejection of IT is a fundamental factor for the success of IT investments in an organization. A person's understanding to rejecting or accepting IT is related to the user's psychological factors.

According to Lewis et al (2003) from the angel of psychological process, the beliefs of a person towards information technology that includes beliefs related to usefulness and ease of use are influenced by three dominant sources, namely: institutional factors, social factor, and individual factors. The dominant influence in the research will be the external variable for the model that explains the main construct of TAM (technology acceptance model). The variable of institutional influence has a very important role in the organization from top management to lower level management. The key role of management is in organizational decision making, including the selection of information technology systems that will be used by the organization. No less important than the influence of institutions, the role of individuals who wrestle with the information technology system itself becomes a significant factor.

Davis et al (1989) used TRA (the theory of reason action) as one of the intention models that has been successful in predicting and explaining one's behavior including IT users. Then introducing the theory adopted from TRA known as the Technology Acceptance Model (TAM), which is specifically used to predict and explain the behavior of computer users. They stated that all other variables that affect the acceptance of information technology are mediated by individual beliefs about the use of concerned information technology. In general, perceived usefulness is a belief related to the results associated with the use of technology and perceived ease of use is a belief that the use of such technology will not be troublesome, said to be the main construct of technology acceptance. When individuals have the perception that using technology can improve their performance in work, then they will see it as a positive thing and do it voluntarily. And so individuals who perceive that the technology is easy to use and will not be troublesome, then they will see it as something positive and will be applied to other jobs. TAM states that behavioral intension to use is determined by two basic beliefs: perceived of usefulness defined to what extent do someone is convinced that using technology will improve the performance of its work and perceived easy of use defined to what extent do someone believes that the use of technology will be free from effort. TAM also states that the impact of external variables on intention to use is mediated by perceived usefulness and perceived ease of use.

In addition to using TAM variables, this study used an external variable for the model that explains the main construct (antecedent) of TAM variables such as institutional factors and individual factors in explaining the acceptance process of Micros Fidelio. Institutional factors are used in decision making by management concerning elections and overall system implementation. Institutional factors in the study consist of top management commitment and local management commitment, where the institutional factors directly influence social factors in this study namely seniority, supervisor, professional colleagues and departmental associates will be included in local management commitment variables (Darono, 2016). Self efficacy and personal innovativeness were used in this study as Individual factors. Self efficacy is based on social cognitive theory that states by seeing others do something, one will have a perception of his or her ability to do the same thing (Lewis et al, 2003). 


\section{THEORETICAL FRAMEWORK}

Technology Acceptance Model (TAM). TAM was first developed by Davis (1989) it was a model used to explain and predict the adoption and use of information systems. TAM is the development of Theory of Reasoned Action (TRA) by adding two main constructs into the model, namely perceived usefulness and perceived easy of use, in addition to other constructs, such as attitudes toward behavior, intent to use and usage. Constructs used in TAM:

- Perceived usefulness: as to what extent do someone believes that using a technology will improve the performance of its work.

- Percieved easy of use: as to what extent do someone believes that the use of technology will be free from effort.

- Attitude toward behavior: the positive or negative feelings of a person when it comes to performing the prescribed behavior.

- Behavior Intention: a person's desire to perform a behavior.

- Actual Use: action taken by a person.

In the development of studies using TAM by Lee et al (2003) classified into 4 stages: model recognition, model validation, model extension, and model elaboration. Model extension is the development of the TAM model by adding external variable that become the cause (antecedent) of the TAM main construct. The external variables in the TAM are the factors outside the five TAM constructs. These variables are the cause of perceived usefulness and perceived easy of use constructs that will reinforce the influence of TAM constructs on the usage of information technology by users. The following are component corelation in the modified TAM model with additional external variables:

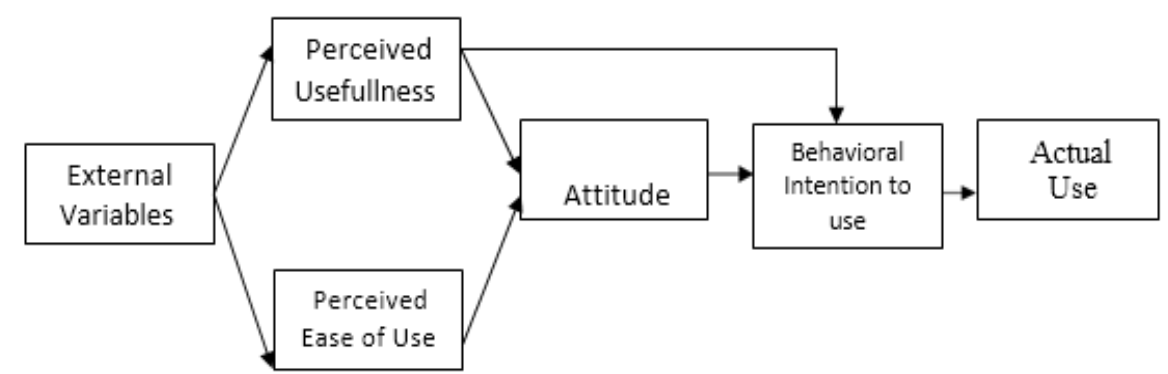

Figure 1 - Correlation between TAM Variables

\section{External Variables of the Study:}

Institutional Factors. Commitment and management support as a necessary factor in a successful implementation of a system. Top management support can play a useful role in resolving disputes and providing a clear signal for any hasitation (Zhang et al, 2003). Institutional factors consist of two variables, namely: Top Management Commitment and Local Management Commitment.

Individual Factors. Individual factors are factors associated with the attitude of people towards their work, age and gender. Individual Factors consists of two variables: Self Efficacy means one's judgment of one's own ability to organize and decide the necessary actions in a situation to achieve certain performance (Bandura, 1994), and Personal Innovativeness means to what extent do a person willing to try new information technology (Agarwal and Prasad, 1998).

\section{RESEARCH FRAMEWORK}

The technology acceptance model is the core theory used in this study. In addition, four external variables used to determine the effect of employee acceptance of Micros Fidelio can be seen in the determinants research framework as follows: 


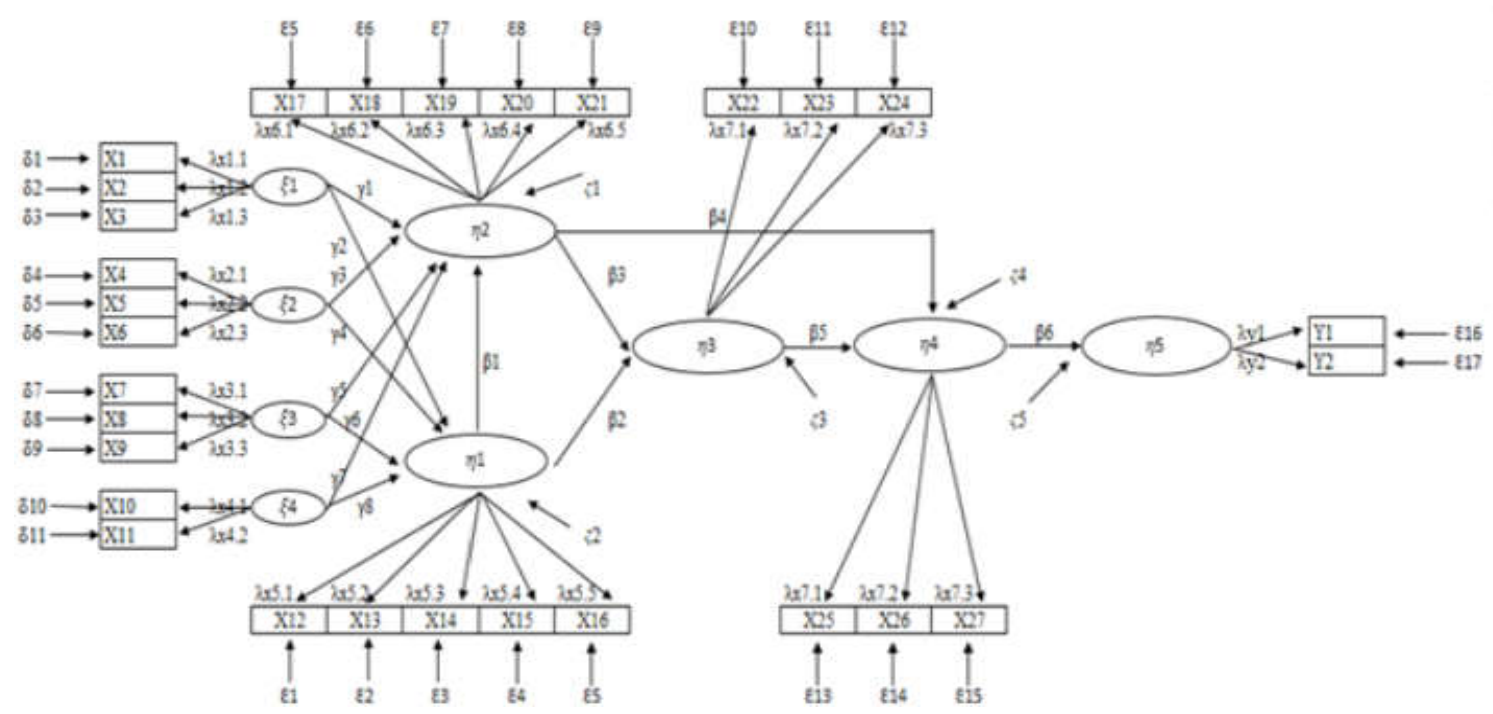

Figure 2 - Path Diagram for Research Framework

\section{RESEARCH HYPOTHESES}

To effectively explain and predict the behavior of information technology users Davis (1989) use rational behavior theory and behavioral theory planned by (Ajzen and Fishbein, 1980) as the basis, combined with the Technology Acceptance Model (TAM) applied to information systems. The research hypotheses are as follows:

- H1a: Top Management commitment positively affect perceived ease of use in the use of Micros Fidelio system;

- H1b: Top management commitment positively affect perceived usefulness of Micros Fidelio system;

- H2a: Local management commitment positively affect perceived ease of use in the use of Micros Fidelio system;

- H2b: Local management commitment positively affect perceived usefulness of Micros Fidelio system;

- H3a: Self-Efficacy positively affect perceived ease of use in the use of Micros Fidelio system;

- H3b: Self-Efficacy positively affect perceived usefulness in the use of Micros Fidelio system;

- H4a: Personal Innovativeness positively affect relationship to perceived ease of use in the use of Micros Fidelio;

- H4b: Personal Innovativeness positively affect perceived ease of use of Micros Fidelio system;

- H5: Perceived ease of use positively affect perceived usefulness in the use of the Micros Fidelio system;

- H6: Perceived ease of use positively affect attitude toward using in the use Micros Fidelio system;

- H7: Perceived usefulness positively affect attitude toward using in the use of Micros Fidelio system;

- H8: Perceived usefulness positively affect Behavioral Intention to use on the Micros Fidelio system;

- H9: Attitude toward using positively affect behavior intention to use on the Micros Fidelio system;

- H10: Behavior intention to use positively affect actual use on the Micros Fidelio system. 
The type of the research was explanatory with survey method approach. This research was conducted at Property Management in Badung-Bali, within period of 2017-2018, because in December 2017-January 2018 Micros Fidelio system application was tested gradually to the managers and empployees. The study population were the entire management and employees of Property Management. While the determination of the sample using proportional sampling which is a sampling method that takes into account the elements or categories in the study population. This technique was used because the population spreads in each division or department that includes: management, back office, villa division, hotel division, and restaurant division.

The research questionnaire was divided into two parts namely part I in the form of open questions about the correspondent profile and part II in the form of closed questions covering all research variables. The question items consist of 30 questions relating to the four external variables and the five TAM variables. Before the questionnaires were distributed to the professional respondents, the questionnaires were tested to 30 accounting master students to obtain valid and reliable data. Respondent data that have been collected then processed and tested by using software PLS 3.0.

This research was recursive which means one way causal model and no reverse direction (feed back loop) and no causal effect (reciprocal). So the problem of un-identified, under-identified or over-identified will not happen. According to Hussein (2015) in the analysis using the PLS, it performed with five stages of testing, they are:

- Outer model analysis. The model defines how each indicator relates to its latent variable. Three tests was performed, they are: Convergent validity, Discriminat validity, and Composite reliability;

- Inner model analysis. Ensure that structural models are built strong and accurate. The three tests conducted were : Evaluation of $\mathrm{R}^{2}$ value means that the variability of endogenous variables can be explained by the exogenous variables, Estimate for Path Coefficients means to indicate the significance of the relation between constructs / variables, Q2 structure (predictive relevance) means to measure how well the observation value generated by the model and its parameter estimation;

- Hypothesis Testing. Hypothesis testing can be seen from the value of $t$-statistics and probability value. To test the hypothesis using a statistical value then for alpha $5 \% \mathrm{t}$ statistics used is 1.96. So the acceptance / rejection criteria of the hypothesis is $\mathrm{Ha}$ accepted and $\mathrm{H} 0$ is rejected when t-statistic> 1.96;

- Constructing Path Diagram by bootstrapping;

- Path diagram conversion into equation system.

The path diagrams translated into equations for structural models and measurement models are as follows:

$$
\begin{gathered}
\eta 1=\gamma 2 \xi 1+\gamma 4 \times \xi 2+y 6 \xi 3+y 8 \xi 4+\zeta 1 \\
\eta 2=\gamma 1 \xi 1+\gamma 3 \times \xi 2+y 5 \xi 3+y 7 \xi 4+\zeta 2 \\
\eta 3=\beta 2 \eta 1+\beta 3 \eta 2+\zeta 3 \\
\eta 4=\beta 4 \eta 2+\beta 5 \eta 3+\zeta 4 \\
\eta 5=\beta 6 \eta 4+\zeta 5
\end{gathered}
$$

\section{RESULTS OF STUDY}

Regarding the demographic characteristic, there were 70 men and 45 women, 71 people with age of $20-29$ years $(62 \%)$, 35 people with age of $30-39(30 \%)$, 9 people with age of $40-49$ years $(8 \%)$, this shows that employees are still productive at work. Employee educational level, highschool 24 people, 54 people with Associate's degree, 34 people with Bachelor's degree, and 2 people with Master's degree. Respondents who work in the front office are as many as 90 people and back office 18 people selected as samples in the study while the total management as many as 7 people, so the use of systems in the company's operational is necessary. 
Sample of 127 respondents was set from 204 population using Isaac and Michael tables. From the determined sample, the questionnaire was distributed to the managers and property management employees through 3 business units and head office. The distribution of questionnaires was done directly to the respondents to anticipate the low returns of respondents. The questionnaire distribution was conducted in January 2018 until February 2018, because the introduction of Micros Fidelio system to the managers and employees beginning in December 2017. 117 copies or 92\% of questionnaires returned. The questionnaire that can be processed were 115 copies or $91 \%$, of which 2 copies were unable to be processed because there were multiple answers to the question items and respondents refused to fill out the new questionnaire. The non-response bias level in the research tested by independent sample t-test showed that through Levene's test, nine research variables had significance value $>0.05$, so it can be concluded that there are similarities between the respondents who returned the questionnaire on time with the respondent who was late.

Convergent Validity is a correlation between the item / indicator score with the construct score. According to Chin (1998) ) individual indicators at the stage of research measurement scale development said to be high if the value of cross loading ranges from 0.50 to 0.60 . In this study the value of cross loading used was 0.60 . Nine constructs has convergent validity $>0.60$.

Table 2 - Cross Loading for Convergent Validity

\begin{tabular}{|r|l|c|l|}
\hline No & Indicator & $\begin{array}{c}\text { Cross } \\
\text { Loading }\end{array}$ & \multicolumn{1}{c|}{ Remark } \\
\hline 1 & X1.1 & 0,893 & Convergent validity fulfilled \\
\hline 2 & X1.2 & 0,898 & Convergent validity fulfilled \\
\hline 3 & X1.3 & 0,720 & Convergent validity fulfilled \\
\hline 4 & X2.1 & 0,806 & Convergent validity fulfilled \\
\hline 5 & X2.2 & 0,885 & Convergent validity fulfilled \\
\hline 6 & X2.3 & 0,719 & Convergent validity fulfilled \\
\hline 7 & X3.1 & 0,850 & Convergent validity fulfilled \\
\hline 8 & X3.2 & 0,884 & Convergent validity fulfilled \\
\hline 9 & X3.3 & 0,788 & Convergent validity fulfilled \\
\hline 10 & X4.1 & 0,686 & Convergent validity fulfilled \\
\hline 11 & X4.2 & 0,891 & Convergent validity fulfilled \\
\hline 12 & X4.3 & 0,709 & Convergent validity fulfilled \\
\hline 13 & X5.1 & 0,759 & Convergent validity fulfilled \\
\hline 14 & X5.2 & 0,798 & Convergent validity fulfilled \\
\hline 15 & X5.3 & 0,672 & Convergent validity fulfilled \\
\hline 16 & X5.4 & 0,694 & Convergent validity fulfilled \\
\hline 17 & X5.5 & 0,721 & Convergent validity fulfilled \\
\hline 18 & X6.1 & 0,787 & Convergent validity fulfilled \\
\hline 19 & X6.2 & 0,828 & Convergent validity fulfilled \\
\hline 20 & X6.3 & 0,700 & Convergent validity fulfilled \\
\hline 21 & X6.4 & 0,767 & Convergent validity fulfilled \\
\hline 22 & X6.5 & 0,798 & Convergent validity fulfilled \\
\hline 23 & X7.1 & 0,869 & Convergent validity fulfilled \\
\hline 24 & X7.2 & 0,879 & Convergent validity fulfilled \\
\hline 25 & X7.3 & 0,684 & Convergent validity fulfilled \\
\hline 26 & X8.1 & 0,818 & Convergent validity fulfilled \\
\hline 27 & X8.2 & 0,834 & Convergent validity fulfilled \\
\hline 28 & X8.3 & 0,813 & Convergent validity fulfilled \\
\hline 29 & Y1 & 0,911 & Convergent validity fulfilled \\
\hline 30 & Y2 & 0,927 & Convergent validity fulfilled \\
\hline & & & \\
\hline
\end{tabular}

Assessed by cross loading the measurements with constructs. The square root value of the square root of average variance extracted (AVE) must be higher than the correlation value between the latent variables. The nine constructs have a high discriminat validity because the root square of the average variance extracted $>$ AVE. 
Table 3 - Square Root of Average Variance Extracted (AVE)

\begin{tabular}{|c|c|c|}
\hline & AVE & The Root Square AVE \\
\hline Top MC & 0.708 & 0.841 \\
\hline Local MC & 0.65 & 0.806 \\
\hline SE & 0.708 & 0.842 \\
\hline PI & 0.684 & 0.827 \\
\hline PEOU & 0.534 & 0.73 \\
\hline PU & 0.604 & 0.777 \\
\hline ATU & 0.665 & 0.816 \\
\hline BI & 0.676 & 0.822 \\
\hline Actual Use & 0.845 & 0.919 \\
\hline
\end{tabular}

A construct said to be reliable if it has a composite reliability value higher than 0.60 (Ghozali, 2014). In this study nine constructs has composite reliability $>0.60$, so that the nine constructs can be said reliable.

Table 4 - Composite Reliability Value

\begin{tabular}{|c|c|c|}
\hline & AVE & $\begin{array}{c}\text { Composite } \\
\text { Reliability }\end{array}$ \\
\hline Actual Use & 0.845 & 0.916 \\
\hline BI & 0.676 & 0.862 \\
\hline ATU & 0.665 & 0.855 \\
\hline PU & 0.604 & 0.884 \\
\hline PEOU & 0.534 & 0.851 \\
\hline PI & 0.684 & 0.865 \\
\hline SE & 0.708 & 0.879 \\
\hline Local MC & 0.65 & 0.847 \\
\hline Ta & 0.700 & 0.70 \\
\hline
\end{tabular}

Inner model were used to evaluate the connection between latent constructs in accordance with the hypothesis in the study, which is the connection between acceptance of Micros Fidelio system as measured by four exogenous constructs with percieved ease of use and percieved usefulness construct on attitudes, interest constructs (Behavioral Intention), and interest construct connection (Behavioral Intention) to the actual usage construct.

The estimated values for coefficient path in the structural model must be significant. Significant obtained through bootstrapping procedure which also yields $T$ value ( $T$-value), where $t_{\text {count }}>t_{\text {table }}$ 1.96. The result shows that there are three variables: Personal innovativeness has no significant effect on perceived easy of use and perceived usefulness, and self efficacy variable has no significant effect on perceived easy of use.

Table 5 - Path Coefficients

\begin{tabular}{|l|c|c|c|c|c|}
\hline & $\begin{array}{c}\text { Original } \\
\text { Sample } \\
(\mathbf{O})\end{array}$ & $\begin{array}{c}\text { Sample } \\
\text { Mean } \\
(\mathbf{M})\end{array}$ & $\begin{array}{c}\text { Standard } \\
\text { Deviation } \\
\text { (STDEV) }\end{array}$ & $\begin{array}{c}\text { Standard } \\
\text { Error } \\
\text { (STERR) }\end{array}$ & $\begin{array}{c}\text { T } \\
\text { Statistics }\end{array}$ \\
\hline BI $>$ Actual Use & 0.631 & 0.638 & 0.067 & 0.067 & 9.437 \\
\hline ATU $>$ BI & 0.299 & 0.298 & 0.125 & 0.125 & 2.387 \\
\hline PU $>$ BI & 0.416 & 0.415 & 0.13 & 0.13 & 3.197 \\
\hline PU $>$ ATU & 0.42 & 0.424 & 0.1 & 0.1 & 4.186 \\
\hline PEOU > ATU & 0.342 & 0.34 & 0.108 & 0.108 & 3.167 \\
\hline PEOU $>$ PU & 0.212 & 0.214 & 0.089 & 0.089 & 2.376 \\
\hline PI $>$ PU & 0.063 & 0.062 & 0.074 & 0.074 & 0.85 \\
\hline PI $>$ PEOU & 0.184 & 0.186 & 0.104 & 0.104 & 1.77 \\
\hline SE $>$ PU & 0.346 & 0.346 & 0.073 & 0.073 & 4.748 \\
\hline SE $>$ PEOU & 0.108 & 0.108 & 0.096 & 0.096 & 1.125 \\
\hline Local MC $>$ PU & 0.159 & 0.16 & 0.075 & 0.075 & 2.115 \\
\hline Local MC $>$ PEOU & 0.269 & 0.278 & 0.109 & 0.109 & 2.464 \\
\hline Top MC $>$ PU & 0.243 & 0.236 & 0.102 & 0.102 & 2.386 \\
\hline Top MC $>$ PEOU & 0.269 & 0.262 & 0.117 & 0.117 & 2.297 \\
\hline
\end{tabular}


$\mathrm{R}^{2}$ value means the amount of variability of endogenous variables capable of being explained by exogenous variables. Chin and Lin (2015) describe the R2 criteria consists of three classifications of $R^{2}$ values: 0.67 means substantial, 0.33 means moderate and 0.19 means weak.

Tabel 6 - Predictive Relevance Criteria

\begin{tabular}{|c|c|c|}
\hline Variabel & R Square & Remark \\
\hline Actual Use & 0.399 & Moderat \\
\hline BI & 0.421 & Moderat \\
\hline ATU & 0.476 & Moderat \\
\hline PU & 0.662 & Substantial \\
\hline PEOU & 0.458 & Moderat \\
\hline
\end{tabular}

The Q-square value $>0$ indicates the model has predictive relevance, but otherwise if the $Q$-square value $\leq 0$ it indicates the model lack predictive relevance. The results show that the model and its parameters have good predictive relevance because the TAM construct has a value $>0$, so the observation value of the construct is good.

The result of hypothesis testing shows that from fourteen hypothesis proposed there were eleven accepted hypothesis and three of them rejected, the hypothesis were: $\mathrm{H} 5$ which means Self Efficacy has no effect on Perceived Easy of Use in the use of Micros Fidelio information system. $\mathrm{H} 7$ which means Personal Innovativeness has no effect on Perceived Easy of Use in the use of Micros Fidelio information system. H8 which means Personal Inovativeness has no effect on Perceived Usefulness in the use of Micros Fidelio information system.

Table 7 - Hypothesis Testing Results

\begin{tabular}{|c|c|c|c|c|c|}
\hline Hypothesis & Variable & Estimates & T Statistic & Relation & Remark \\
\hline 1 & Top MC $\rightarrow$ PEOU & 0.243 & 2.297 & Direct & H1 Supported \\
\hline 2 & Top MC $\rightarrow$ PU & 0.269 & 2.386 & Direct & H2 Supported \\
\hline 3 & Local MC $\rightarrow$ PEOU & 0.159 & 2.464 & Direct & H3 Supported \\
\hline 4 & Local MC $\rightarrow$ PU & 0.269 & 2.115 & Direct & H4 Supported \\
\hline 5 & $\mathrm{SE} \rightarrow \mathrm{PEOU}$ & 0.346 & 1.125 & Direct & H5 Not Supported \\
\hline 6 & $\mathrm{SE} \rightarrow \mathrm{PU}$ & 0.108 & 4.748 & Direct & H6 Supported \\
\hline 7 & $\mathrm{PI} \rightarrow \mathrm{PEOU}$ & 0.063 & 1.77 & Direct & H7 Not Supported \\
\hline 8 & $\mathrm{PI} \rightarrow \mathrm{PU}$ & 0.184 & 0.85 & Direct & H8 Not Supported \\
\hline 9 & $\mathrm{PEOU} \rightarrow \mathrm{PU}$ & 0.212 & 2.376 & Direct & H9 Supported \\
\hline 10 & $\mathrm{PEOU} \rightarrow \mathrm{ATU}$ & 0.342 & 3.167 & Direct & H10 Supported \\
\hline 11 & $\mathrm{PU} \rightarrow \mathrm{ATU}$ & 0.420 & 4.186 & Direct & H11 Supported \\
\hline 12 & $\mathrm{PU} \rightarrow \mathrm{BI}$ & 0.416 & 3.197 & Direct & H12 Supported \\
\hline 13 & $\mathrm{ATU} \rightarrow \mathrm{BI}$ & 0.299 & 2.387 & Direct & H13 Supported \\
\hline 14 & $\mathrm{BI} \rightarrow \mathrm{Actual}$ Use & 0.631 & 9.437 & Direct & H14 Supported \\
\hline
\end{tabular}

\section{DISSCUSSION OF RESULTS}

According to Davis (1989) Technology Acceptance Model (TAM) construct has a positive influence on the acceptance of information technology systems. The result of hypothesis test table shows the external variable construct of the model namely Institutional Factor which consist of: Top management commitment, Local management commitment positively affect perceived easy of use and perceived usefulness in the use of Micros Fedelio information system, it means either top or lower management gave a huge contribution in the system alteration of a company. The results of this study were in accordance with several previous studies, such as: (Aristo, 2017), (Utama, 2012), and (Lewis et al, 2003).

Individual Factor consisting of Self-Efficacy and Personal Innovativeness, where only Self-Efficacy has a positive effect on perceived usefulness in the use of information systems Micros Fidelio, it means the ability of the employees to see the usefulness of the system to assist them in their work activities. Previous studies that support these results include: 
(Suardikha et al, 2012), (Lewis et al, 2003), (Kartika, 2009) dan (Abdullah et al, 2013). While Self-Efficacy has no effect on perceived use of use in the use of Micros Fidelio information system, it means a person's judgment of his or her ability does not affect the ease of use of the Micros Fidelio system. Previous studies support these results include: (Santoso and Setiawan, 2017), dan (Medyawati et al, 2011).

Personal Innovativeness has no influence on perceived ease of use and perceived usefulness in the use of Micros Fidelio system, it means employee characteristics regarding the Micros Fidelio system was a system that is easy to use and useful for their work does not affect their point of view. Several previous studies support this finding, such as: (Hartini, 2011), (Aisyah et al, 2013), dan (Karjaluoto et al, 2014).

Technology Acceptance Model (TAM) construct namely, Perceived Ease of Use (PEOU) positively affect Perceived of Usefulness (PU) and Attitude Toward Using (ATU), Perceived of Usefulness (PU) positively affect Attitude Toward Using (ATU) and Behavioral Intention $\mathrm{BI}$ ), and Behavioral Intention (BI) affect Actual use (AU). This means that the ease of use of the Micros Fidelio system and the usefulness of the system itself affects the attitude of managers and employees interest of using the Micros Fidelio system, as well as their decision to apply the system in their work. Several studies support this results include: (Kartika, 2009), (Muntianah et al, 2012), (Marini, 2012), (Armanely \& Syafrudin, 2012), (Sulistyarini, 2012), (Aisyah et al, 2013), (Kartika, 2013), (Abdullah et al, 2013), (Hanggono et al, 2015), and (Sari, 2016).

Path diagram was formed from the output of Smart PLS in accordance with the framework of the research determinant:

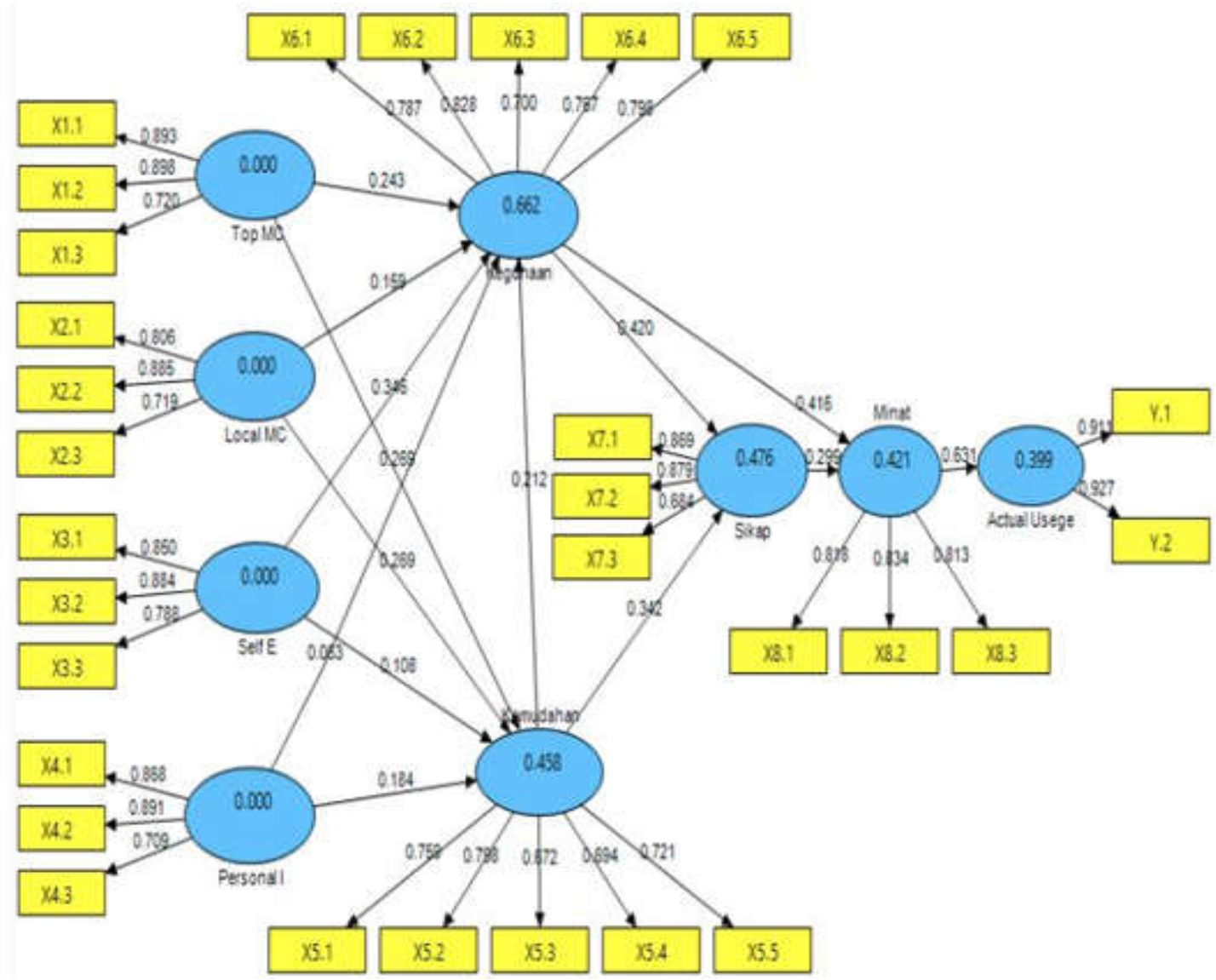

Image 3 - Path diagram of structural equations with Smart PLS

Conversion of Path Diagram into Equation System. The value of the loadings factor and standard error for each indicator will be used to construct the equation of the measurement model (outer models), so that the equation presented as follows: 
Table 8 - Measurement Model Equation

\begin{tabular}{|c|c|c|}
\hline No & Measurment Model & Real Measurement Model \\
\hline 1 & $x 1.1=\lambda x 1.1 \xi+\delta 1$ & $x 1.1=0.893 \xi+0.032$ \\
\hline 2 & $x 1.2=\lambda x 1.2 \xi+\delta 2$ & $x 1.2=0.896 \xi+0.029$ \\
\hline 3 & $x 1.3=\lambda x 1.3 \xi+\delta 3$ & $x 1.3=0.720 \xi+0.038$ \\
\hline 4 & $x 2.1=\lambda x 2.1 \xi+\delta 4$ & $x 2.1=0.806 \xi+0.039$ \\
\hline 5 & $x 2.2=\lambda x 2.2 \xi+\delta 5$ & $x 2.2=0.885 \xi+0.030$ \\
\hline 6 & $x 2.3=\lambda x 2.3 \xi+\delta 6$ & $x 2.3=0.719 \xi+0.052$ \\
\hline 7 & $x 3.1=\lambda x 3.1 \xi+\delta 7$ & $x 3.1=0.850 \xi+0.041$ \\
\hline 8 & $x 3.2=\lambda x 3.2 \xi+\delta 8$ & $x 3.2=0.884 \xi+0.028$ \\
\hline 9 & $x 3.3=\lambda x 3.3 \xi+\delta 9$ & $x 3.3=0.788 \xi+0.043$ \\
\hline 10 & $x 4.1=\lambda x 4.1 \xi+\delta 10$ & $x 4.1=0.868 \xi+0.049$ \\
\hline 11 & $x 4.2=\lambda x 4.2 \xi+\delta 11$ & $x 4.2=0.891 \xi+0.042$ \\
\hline 12 & $x 4.3=\lambda x 4.3 \xi+\delta 12$ & $x 4.3=0.709 \xi+0.062$ \\
\hline 13 & $x 5.1=x 5.1 \eta 1+\varepsilon 1$ & $x 5.1=0.759 \eta 1+0.028$ \\
\hline 14 & $x 5.2=x 5.2 \eta 1+\varepsilon 2$ & $x 5.2=0.798 \eta 1+0.030$ \\
\hline 15 & $x 5.3=x 5.3 \eta 1+\varepsilon 3$ & $x 5.3=0.672 \eta 1+0.033$ \\
\hline 16 & $x 5.4=x 5.4 \eta 1+\varepsilon 4$ & $x 5.4=0.694 \eta 1+0.037$ \\
\hline 17 & $x 5.5=x 5.5 \eta 1+\varepsilon 5$ & $x 5.5=0.721 \eta 1+0.025$ \\
\hline 18 & $x 6.1=x 6.1 \eta 2+\varepsilon 6$ & $x 6.1=0.787 \eta 2+0.019$ \\
\hline 19 & $x 6.2=x 6.2 \eta 2+\varepsilon 7$ & $x 6.2=0.828 \eta 2+0.018$ \\
\hline 20 & $\square 6.3=\square 6.3 \square 2+\square 8$ & $\square 6.3=0.700 \square 2+0.021$ \\
\hline 21 & $\square 6.4=\square 6.4 \square 2+\square 9$ & $\square 6.4=0.767 \square 2+0.021$ \\
\hline 22 & $\square 6.5=\square 6.5 \square 2+\square 10$ & $\square 6.5=0.798 \square 2+0.021$ \\
\hline 23 & $\square .1=\square 7.1 \square 3+\square 11$ & $\square 7.1=0.869 \square 3+0.030$ \\
\hline 24 & $\square .2=\square 7.2 \square 3+\square 12$ & $\square 7.2=0.879 \square 3+0.031$ \\
\hline 25 & $\square 7.3=\square 7.3 \square 3+\square 13$ & $\square 7.3=0.684 \square 3+0.045$ \\
\hline 26 & $\square 8.1=\square 8.1 \square 4+\square 14$ & $\square 8.1=0.818 \square 4+0.033$ \\
\hline 27 & $\square 8.2=\square 8.2 \square 4+\square 15$ & $\square 8.2=0.834 \square 4+0.037$ \\
\hline 28 & $\square .3=\square 8.2 \square 4+\square 16$ & $\square 8.3=0.813 \square 4+0.034$ \\
\hline 29 & $\square 1=\square 1 \square 5+\square 17$ & $\square 1=0.911 \square 5+0.030$ \\
\hline 30 & $\square 2=\square \square 2 \square+\square 18$ & $\square 2=0.270 \square 5+0.031$ \\
\hline & & \\
\hline & & \\
\hline 2 & &
\end{tabular}

\section{CONCLUSION}

The purpose of the study was to analyze and find empirical prove about the acceptance of Micros Fidelio information system by the employee of Property Management using TAM (Technology Acceptance Model). Based on the results and discussion in the study, it can be concluded that:

Top management commitment has positively affect perceived easy of use in the use of Micros Fidelio information systems. This indicates that management decisions regarding alteration of the information systems affect the perceived ease of use of Micros Fidelio.

Top management commitment positively affects perceived usefulness in the use of Micros Fidelio information systems. This indicates that management decisions regarding alteration of the information systems affect the perceived usefulness of Micros Fidelio.

Local management commitment positively affect perceived easy of use in the use of Micros Fidelio information systems. This indicates that the support of middle and lower level management regarding alteration of the information systems affect the perceived ease of use of Micros Fidelio.

Local management commitment positively affects perceived usefulness in the use of Micros Fidelio information systems. This indicates that the support of middle and lower level management regarding alteration of the information systems affect the perceived usefulness of Micros Fidelio.

Self-Efficacy has no effect on perceived easy of use in the use of Micros Fidelio information systems. Indicates that the level of individual ability of the employees regarding alteration of the information system has no effect on the perceived ease of use of Micros Fidelio.

Self-Efficacy positively affects perceived usefulness in the use of Micros Fidelio information systems. Indicates that the level of individual ability of the employees regarding 
alteration of the information system affect the perceived usefulness of Micros Fidelio in carry out their works.

Personal Innovativeness has no effect on perceived easy of use in the use of Micros Fidelio information systems. Indicates that employee characteristics regarding alteration of the information systems has no effect on perceived ease of use of Micros Fidelio.

Personal Innovativeness has no effect on perceived of usefulness of Micros Fidelio information systems. Indicates that employee characteristics regarding alteration of the information systems has no effect on perceived usefulness of Micros Fidelio.

Percieved ease of use positively affects perceived usefulness in the use of Micros Fidelio. Indicates connection between perceived ease of use and the usefulness level of concerned information system.

Percieved ease of use positively affect attitude toward using in the use of Micros Fidelio. Indicates connection between perceived ease of use of information system and the employee attitude toward using Micros Fidelio.

Percieved usefulness positively affect attitude toward using in the use of Micros Fidelio information system, indicates perceived of usefulness affect the employee acceptance toward Micros Fidelio.

Percieved usefulness positively affect behavioral intention to use in the use of Micros Fidelio information system, indicates connection between perceived of usefulness and employee intension to use or not to use Micros Fidelio.

Attitude toward using positively affect behavioral intension to use Micros Fidelio information system, indicates connection between employee attitude toward using and their behavioral intention to use Micros Fidelio.

Behavioral intention to use positively affect actual use in the acceptance of Micros Fidelio Information System, indicates connection between employee desire to use new system and the actual use of Micros Fidelio which is information systems that facilitate employee work.

The result of the study shows there were eleven accepted hypothesis of fourteen hypotheses proposed. Three of two hypotheses of exogenous single variable namely self efficacy and personal innovativeness indicate the absence of acceptance toward Micro Fidelio system. This proves that the transition process from Raptor to Micros system cannot be explained entirely by the Technology Acceptance Model, there are things beyond the model that affect it. Therefore, the implication that can be drawn was that the application of a new system can be done without considering the level of ability of employees and the level of willingness of employees in the acceptance of a system toward the perceived of ease of use and the usefulness of the system. This is related to the willingness of employees to be willing or not in using the system. It is important for the company to take notice in applying a new system because it relates to the cost and benefits (cost benefit) of a new system. But that does not mean system changes can not be done but the system can be designed in a user friendly so it will be easier to be applied by the employees, because the dificullty of a system can be overcome by continue training dan socialization about the new system.

\section{LIMITATIONS AND FURTHER RESEARCH}

This study has several limitations, as follows:

- This study was conducted on organizations that have mandatory system so that employee acceptance of the application of a new system must be considered, because it will be the key to successful implementation of new systems in the future.

- The scale of this study was organizational not industrial so extra caution was needed when generalize the results of the study. This study was conducted on property management that has several business units such as hotels, villas and restaurants so that the results of the study will be broader than just one business unit only.

Suggestions that can be given in this research:

- Can use TAM other external variables such as institutional factors, social factors and individual factors simultaneously. 
- Can be done on several organizations that have different industrial scale so that the results of the study can be generalized.

- Can use different analytical tools such as AMOS, LISREL with larger sample.

\section{REFERENCES}

1. Abdullah, F. Ward, R.Catterall S., Hill, P. A. and W. (2013) 'An investigation of the factors that influence engagement with CPD within e-portfolios used for accredited Higher Education course Original Citation accredited Higher Education course . In : Proceedings of Computing a'.

2. Agarwal, R. and Prasad, J. (1998) 'The antecedents and consequences of user perceptions in information technology adoption', Decision Support Systems, 22, pp. 1529.

3. Aisyah, M. N., Nugroho, M. A. and Sagoro, E. M. (2013) 'Pengaruh Technology Readiness Terhadap Penerimaan Teknologi Komputer Pada Umkm Di Yogyakarta', Jurnal Economia, 10, pp. 105-119.

4. Ajzen, I. and Fishbein, M. (1980) 'Theory Of Reasoned Action / Theory Of Planned Behavior', Social Psychology, 2007, pp. 67-98. Available at: http://hsc.usf.edu/ kmbrown/TRA_TPB.htm.

5. Aristo, J. (2017) 'Proyek dan Keterlibatan Pengguna terhadap Kesuksesan Implementasi Enterprise Resouce Planning', 2(2), pp. 147-154.

6. Bandura, A. (1994) 'Bandura Self-efficacy defined', Encyclopedia of Human Behavior, pp. 71-81. Available at: http://www.uky.edu/ eushe2/Bandura/BanEncy.html.

7. Chin, J. and Lin, S. C. (2015) 'Investigating Users' Perspectives in Building Energy Management System with an Extension of Technology Acceptance Model: A Case Study in Indonesian Manufacturing Companies', Procedia Computer Science. Elsevier Masson SAS, 72, pp. 31-39. doi: 10.1016/j.procs.2015.12.102.

8. Chin, W. (1998) 'The partial least squares approach to structural equation modeling', Modern methods for business research, 295(2), pp. 295-336. doi: 10.1016/j.aap.2008.12.010.

9. Compeau, D. and Higgins, C. (1995) 'Application of social cognitive theory to training for computer skills', Information systems research, 6(2), pp. 118-143. doi: 10.1287/isre.6.2.118.

10. Darono, A. (2016) 'Penggunaan teori institusional dalam penelitian teknologi informasi dan komunikasi di Indonesia', (June 2012).

11. Davis, F. (1989) 'Perceived Usefulness, Perceived Ease Of Use, And User Accep', MIS Quarterly, 13(3), p. 319. doi: 10.2307/249008.

12. Davis, F., Bagozzi, R. and Warshaw, P. (1989) 'User Acceptance Of Computer Technology: A Comparison Of Two Theoretical Models', Management Science, 35(8), p. 982. doi: $10.2307 / 2632151$.

13. Ghozali, I. (2014) 'Partial Least Squares Konsep, Teknik dan Aplikasi Menggunakan Program Smartpls 3.0', (MI), p. 290.

14. Hanggono, A. A., Handayani, S. R. and Susilo, H. (2015) 'Analisis Atas Praktek TAM (Technology Acceptance Model) Dalam Medukung Bisnis Online Dengan Memanfaatkan Jejaring Sosial Instagram', Jurnal Administrasi Bisnis, 26(1), pp. 1-9. doi: administrasibisnis.studentjournal.ub.ac.id.

15. Hartini, S. (2011) 'Pengembangan Model TAM: Expertice dan Innovativeness sebagai Variabel Moderator Studi Pada Penggunaan E-Banking', 1(2), pp. 155-164.

16. Hussein, A. S. (2015) 'Penelitian Bisnis dan Manajemen Menggunakan Partial Least Squares (PLS) dengan SmartPLS 3.0', Modul Ajar, pp. 1-29.

17. Karjaluoto, H. et al. (2014) 'Intention to use mobile customer relationship management systems', Industrial Management \& Data Systems, 114(6), pp. 966-978. doi: 10.1108/IMDS-11-2013-0480.

18. Kartika (2013) 'Technology Acceptence Model: Menguji Keefektivan Penerimaan Sistem Informasi Terpadu (Sister) Di Lingkungan Universitas Jember', (November), pp. 1-27. 
19. Kartika, S. E. (2009) Analisis Proses Penerimaan Sistem Informasi iCons dengan Menggunakan Technology Acceptance Model pada Karyawan PT. Bank Negara Indonesia (PERSERO) TBK di Kota Semarang.

20. Lee, Y., Kozar, K. A. and Larsen, K. R. T. (2003) 'the Technology Acceptance Model: Past , Present , and Future', Communications of the Association for Information Systems, 12(1), pp. 752-780.

21. Lewis, W., Agarwal, R. and Sambamurthy, V. (2003) 'Sources of influence on beliefs about information technology use: An empirical study of knowledge workers. , 657-678.', MIS Quarterly, 27(4), pp. 657-678. doi: 10.1017/CBO9781107415324.004.

22. Marini (2012) 'Kajian Penggunaan Software AMOS / LISREL Berdasarkan Pendekatan TAM Studi Kasus Penggunaan Software pada Pemodelan Persamaan Struktural ( SEM ) di Perguruan Tinggi', Seminar Nasional Aplikasi Teknologi Informasi, 2012(Snati), pp. 15-16.

23. Medyawati, H., Christiyanti, M. and Yunanto, M. (2011) 'E-Banking Adoption Analysis Using Technology Acceptance Model (TAM): Empirical Study of Bank Customers in Bekasi City', International Journal of Modeling and Optimization, 14(201 1), pp. 91-95. Available at: www.ipedr.com/vol14/17-ICIMS2011S00029.pdf.

24. Muntianah, S. T., Astuti, E. S. and Azizah, D. F. (2012) 'Pengaruh Minat Perilaku Terhadap Actual Use Teknologi Informasi dengan Pendekatan Technology Acceptance Model (TAM)', Profit Universitas Brawijaya Malang, 6(1), pp. 88-113.

25. Normasari, S., Kumadji, S. and Kusumawati, A. (2013) 'Pengaruh Kualitas Pelayanan Terhadap Kepuasan Pelanggan, Citra Perusahaan Dan Loyalitas Pelanggan', Jurnal Administrasi Bisnis (JAB), 6(2), pp. 1-9.

26. Santoso, W. and Setiawan, D. (2017) 'Faktor-Faktor Yang Mempengaruhi Niat Penggunaan Approweb Oleh Account Representative Direktorat Jenderal Pajak', Ecojoin.Org, XXI(02), pp. 232-252. Available at: http://www.ecojoin.org/index.php/EJA/article/view/197.

27. Sari, E. N. (2016) 'Analisis Faktor Dalam Menggunakan Layanan E-BILL Dengan Pendekatan Technology Acceptance Model ( TAM )', 5(April), pp. 1-23.

28. Sriwidh Armanely \& Vina syafrudin (2012) 'An Empirical Study of Accounting Software Acceptance among Bengkulu City Students', 112, pp. 99-112.

29. Suardikha, I. M. S. et al. (2012) 'Pengaruh Implementasi Budaya Tri Hita Karana Terhadap Penggunaan Sistem Informasi Akuntansi Dimediasi Keyakinan-Diri Atas Komputer, Keinovatifan Personal, Persepsi Kegunaan, Dan Persepsi Kemudahan Penggunaan Pada Bank Perkreditan Rakyat Di Bali', SNA XV Universitas Lambung Mangkurat Banjarmasin, pp. 1-45.

30. Sulistyarini. S (2012) 'Pengaruh Minat Individu terhadap penggunaan Mobile Banking: Model kombinasi Technology Acceptance Model (TAM) dan Theory of Planned Behavior (TPB)', pp. 1-20.

31. Utama, A. (2012) 'Pengaruh faktor institusional, sosial serta individu terhadap persepsi manfaat menggunakan teknologi informasi'.

32. Zhang, L. et al. (2003) 'Critical success factors of enterprise resource planning systems implementation success in China', p. 10. 